\title{
TUDOMÁNYTÖRTÉNET ÉS/VAGY ISMERETTERJESZTÉS? KÉMIKUSOK, TALÁLMÁNYOK, FELFEDEZÉSEK
}

A Természettudomány háborúban és békeidőben című kötet szerzője egyetemi tanár, az elektrokémia nemzetközileg is elismert kutatója. Tudománytörténeti munkái sorában ez a negyedik kötet, amely a Typotex Kiadó gondozásában jelent meg. A mü alcíme („Kémikusok, találmányok, felfedezések”) a tematikát egy kicsit szükíti, ami a szerző szakmáját tekintve érthető, de ehhez némi magyarázat azért kívánkozik.

Az Encyclopedia Britannica korábbi köteteiben a kémia címszónál az szerepelt, hogy központi tudomány. Ez nem valamiféle fennsőbbségtudat kinyilvánítása, pusztán annak tudatosítása, hogy a kémia az a tudomány, ahonnan a legtöbb elágazás kezdődik más tudományterületek felé (Balaban, A.T., Klein, D.J.: Is chemistry 'The Central Science'? How are different sciences related? Co-citations, reductionism, emergence, and posets. Scientometrics, 2006, 69, 615-637.), ami érthető, hiszen ha anyagokról van szó, a kémia tudománya megkerülhetetlen. Ezt a tényt fejezi ki, hogy az Amerikai Kémiai Társaság (ACS) néhány éve indított nyílt hozzáférésű folyóirata az ACS Central Science címet kapta. Persze mindez nem feltétlenül magától értetődő, hiszen ha fotoszintézisről, kohászatról vagy kenyérsütésről van szó, akkor valószínüleg nem a kémia lesz a legelső fogalom, ami eszünkbe jut, pedig ezekben a jelenségekben/tevékenységekben is döntő szerepe van a kémiának. Ezt fejezi ki néhai Kálmán Alajos, a Magyar Kémikusok Egyesülete egykori elnökének megállapítása, aki szerint a kémia rejtőzködő tudomány (Természet Világa, 2007/I. különszáma, 138, 3).

Ezek után vizsgáljuk meg részletesebben, hogy Inzelt György mivel és hogyan foglalkozik legújabb könyvében. A kérdéses mü hét, különböző hosszúságú fejezetre tagozódik, amelyek között laza kapcsolat van. A könyvben a 18-19. század és a 20. század elejének tudománnyal kapcsolatba hozható eseményeivel ismerkedhetünk meg széles társadalmi összefüggésekbe ágyazva. Nehéz magyarázatot találni arra, hogy a szerző miért éppen ezekről a témákról írt, bár a kötet előszavából kiderül, hogy számos fejezet korábban már megjelent a Magyar Kémikusok Lapjában. Természetesen egymástól független esszéknek is van létjogosultsága egy kötetben, de egy egységesebb, jobban követhető gondolatmenet, egy vezérmotivum a kötet előnyére vált volna. Az a feltételezés, hogy a ,...könyv történeteiből mindenki le tudja vonni a tanulságokat" (Bevezetés, 20. o.), nem elegendő szerkesztési elvnek.

Az első három fejezet nagyrészt a köztudatban rögzült ,,ismeretek” felülvizsgálatával és cáfolatával foglalkozik. Lomonoszov esetében a szerző részletesen 
bemutatja, hogy a polihisztor korántsem alkotott olyan jelentőset, mint azt sokan feltételezik, inkább a szerencsés körülményeknek és a szovjet időkben is tévesen táplált nemzeti öntudat túlkapásának köszönheti mai ismertségét. A mítoszrombolás persze nem hálás feladat, pl. Leonardo da Vinci soha meg nem valósított müszaki alkotásai sem valószínü, hogy megingatják a müvész rajongóinak joggal népes táborát (Szabadváry F.: Egy túlértékelt technikus: Leonardo da Vinci. Orvostörténeti Közlemények, 1997, 158-165., 227-231., http://www.ponticulus. hu/rovatok/errata/szabadvary-1.html). Kitaibel Pál tevékenységének ismertetése közben a tellúr felfedezése körüli prioritási vitákba bonyolódhatunk bele, és a megfelelő tudományos publikálás fontosságának korai állatorvosi lovával találkozhatunk. Than Károly esetében megtudhatjuk, hogy az említett kutatót szerteágazó tevékenysége akadályozta meg abban, hogy szerves kémiai kutatásainak több időt szenteljen; ezt meghagyta későbbi neves utódainak.

A negyedik fejezetben a Nobel-díjas fizikai kémikus, Wilhelm Ostwald tudományos, de még inkább tudományszervezői tevékenységébe pillanthatunk be, javarészt nemrég angolul megjelent önéletrajza alapján. A szerző rajongása egy ilyen nagy formátumú kutató élete és tevékenysége iránt érthető, de más források bővebb, kritikai elemzése fontos lett volna egy teljesebb kép megrajzolásához.

Az ötödik fejezet valódi tudomány- és ipartörténet a kiegyezés korából. Folyóiratok, találmányok, gyárak, vállalkozók: mind megannyi fontos adalék egy, a magyar történelem szempontjából meghatározó korszakból.

A hatodik fejezet a leghosszabb és egyúttal a legösszetettebb, ami érthetö, hiszen az első világháború és következményei döntő hatást gyakoroltak a modern európai társadalmak fejlődésére. A mindenkit érintő eseményekben a kutatók sorsa is sajátos fordulatot vet, ki a háború mellett, ki ellene foglalt állást. Az erkölcsi döntések súlya elől senki nem menekülhetett: aki nem tudott eddig róla, megdöbbenve olvashatta, hány jeles, köztük Nobel-díjas kutató vett részt tevékenyen, pl. a harci gázok fejlesztésében.

A hetedik fejezet a kémiai elemek periódusos rendszerével, elsősorban az új elemek felfedezésével zárja a művet. Talán ez az a fejezet (minden érdekessége ellenére), amely leginkább különbözik a többitől.

A szerző óriási adathalmazzal dolgozik, amelyben otthonosan mozog, és ami ugyanakkor a témában kevéssé járatos olvasó számára szédítő lehet. A sok adat magát a szerzőt is lenyügözi, és gyakran nem tud választani fontos és kevésbé fontos (vagy egyenesen jelentéktelen, csupán ,érdekes”) tények között. Ez a munkamódszer nagyon megnehezíti a könyv befogadását: nem lehet elvárni, hogy a téma iránt érdeklődő átlagos olvasó ugyanazzal a lelkesedéssel merüljön el a kötet hatalmas tényanyagában, mint a jeles szerző. Úgy tűnik, maga a szerző sem döntötte el, kinek szánja a müvét (laikusoknak vagy szakembereknek?), és milyen jellegü könyvet ír (ismeretterjesztő alkotást vagy tudománytörténetet?). Elképzelhető, hogy a feltételezés vezette a szerzőt, hogy ha a kedvenc területéről, 
a tudománytörténetrôl elég részletesen ír, akkor az automatikusan vonzóvá teszi az általában a tudományt és persze szükebb szakterületét, a kémiát is. Fájdalom, de ilyen automatizmus nem létezik (mindezt szakmabeliként és ismeretterjesztöként is alá tudom támasztani). A tudománytörténet megfelelő adagban valóban segítheti a tudományos ismeretek népszerüsítését, azonban nagyon keskeny ez a mezsgye: a túl sok adat és nehezen követhető összefüggés éppen az ellenkező hatást érheti el, elriasztja a téma iránt érdeklődőt. Kár, mert a kötet gazdag mondandója az „átlagos” olvasó számára egy idő után így követhetetlen és unalmas lesz (mint az a Magyar Nemzet recenziójában is felbukkan: https://magyarnemzet.hu/lugas-rovat/kemikusok-frontvonalban-8584515/). Szerencsés lett volna, ha egy szerkesztő erre felhívja a szerző figyelmét, mert a kötet javára vált volna.

A sok adat óhatatlanul azt a veszélyt rejti, hogy tévedések is belekerülnek a mübe. Szerencsére ebböl kevés van (pl. Lomonoszov esetében az 1830-as évszám említése a kolostoriskolába lépéseként 1730 helyett, 27. o.; Emil Fischer öngyilkossága és egyik fia halála körülményeinek téves ismertetése, 207. o. (vö. Remane, H.: Emil Fischer. Biographien hervorragender Naurwissenschaftler, Techniker und Mediziner. BSB B. G. Teubner Verlagsgesellschaft: Leipzig, 1984, 35-36., 65. o.).

A kötetet irodalomjegyzék és egy 18 oldalas névtár zárja, utóbbi mintegy 700 személyt foglal magában. Nem igazi mutató ez, mert a pontos oldalszámok helyett a fejezeteket sorolja fel, ami pl. az első világháborúról szóló 80 oldalas fejezetben vajmi kevés segítséget jelent ahhoz, hogy az adott személyre vonatkozó információ pontos helyét megtaláljuk a könyvben. A szerző már korábban, más kiadónál megjelent müvében is élt ezzel a módszerrel, ezért feltételezhetjük, hogy kényszerüségből tette ezt. Sajnálatos, hogy a hazai könyvkiadásban a szerzők nem kapnak megfelelő segítséget a kiadóktól színvonalas és jól használható mutatók összeállításához, pedig ma már kitűnő szoftverek könnyítik meg ezt a munkát.

(Inzelt György: Természettudomány háborúban és békeidöben. Kémikusok, találmányok, felfedezések. Budapest: Typotex Kiadó, 2020, 323 o.)

Kovács Lajos

tudományos fömunkatárs

Szegedi Tudományegyetem Orvosi Vegytani Intézet 